\title{
Modelling the Effects of Financial Liberalization and Economic Growth in Liberia: Evidence from Combined Cointegration Test
}

James Karmoh Sowah Jr

Lefke Avrupa Universitesi https://orcid.org/0000-0001-5423-3019

Dervis Kirikkaleli ( $\nabla$ dkirikkaleli@eul.edu.tr)

https://orcid.org/0000-0001-5733-5045

\section{Research}

Keywords: Financial Liberalization, Deposit Interest Rates, Savings, Economic Growth, Combined Cointegration Test

Posted Date: April 29th, 2020

DOl: https://doi.org/10.21203/rs.3.rs-24707/v1

License: (c) (i) This work is licensed under a Creative Commons Attribution 4.0 International License.

Read Full License 
Modelling the Effects of Financial Liberalization and Economic Growth in Liberia:

Evidence from Combined Cointegration Test

\author{
James Karmoh Sowah Jr. \\ European University of Lefke \\ Faculty of Economic and Administrative Science \\ Department of Business Administration \\ Lefke, Northern Cyprus \\ TR-10 Mersin, Turkey \\ Email: sowahjamesk@yahoo.com \\ Dervis Kirikkaleli \\ European University of Lefke \\ Faculty of Economic and Administrative Science \\ Department of Banking and Finance \\ Lefke, Northern Cyprus \\ TR-10 Mersin, Turkey \\ Email: $\underline{\text { dkirikkaleli@eul.edu.tr }}$
}




\title{
Modelling the Effects of Financial Liberalization and Economic Growth in Liberia: Evidence from Combined Cointegration Test
}

\begin{abstract}
The research aimed was to determine the long-run relationship between financial liberalization, savings mobilization, and investment with a resultant effect on economic growth in the context of the Liberian economy as articulated by McKinnon and Shaw's hypothesis. The study employed time series data spanning from 1980 to 2016 and extracted from World Development Indicators (WDI). The data were analysed using econometric techniques of Combined Cointegration test, Dynamic Ordinary Least Squares (DOLS), Fully Modified Ordinary Squares (FMOLS), and Canonical Cointegration Regression (CCR). To our knowledge, no studies have investigated the effects of financial liberalization and economic growth in Liberia, expressly, employing Combined Cointegration Test. Our findings reveal (i) coefficient of the financial liberalization variable is positive and significant for Liberia, thus support the McKinnon and Shaw hypotheses. (ii) We found combined cointegration among the estimated models. We recommended that policymakers should refrain from any policy that will adversely affect the deposit interest rates considering its immense impact on savings mobilization, gross investment, and the overall economic growth. Furthermore, improving the level of competition will compel deposit-taking financial institutions to raise deposit interest rates in a bid to attract more depositors with a consequential reduction in the interest rates spread.
\end{abstract}

Key Words: Financial Liberalization, Deposit Interest Rates, Savings, Economic Growth, Combined Cointegration Test

JEL Codes: F3, G0, E4, F43, C1

\section{Introduction}

Financial liberalization is a deliberate government policy to deregulate credit and interest rates as well as removing all forms of barriers that are not encouraging private and foreign financial institutions in the financial market. It also involves removing some form of restrictions on 
foreign financial transactions (Bumann, Hermes, \& Lensink, 2013). It brings about real positive interest rates, which equate the demand for deposits with the supply of savings (McKinnon (1973; and Shaw, 1973), and it expresses the views that a slightly higher interest rate will lead to increased savings and financial intermediation and also improve the efficiency of using savings. For a decade now, the relevance of financial liberalization in enhancing economic growth remains an exciting topic among scholars and policymakers. Generally, financial liberalization provides the platform for countries to deregulate or eliminate restrictions on their financial markets and liberalize investment funds (Stiglitz, 2000).

The benefits of financial liberalization are assumed to be many. First, with the introduction of market principles, it produces higher interest rates on deposits, which should bring about an increase in the volume of savings, thereby increasing the availability of funds for investment. Second, financial liberalization is supposed to increase competition in the financial market, which might lead to a reduction in the lending rate or the introduction of more financial products that might bring about more financial intermediation as well as a reduction in credit constraint for firms. Third, it is supposed to allocate capital toward higher-return projects, which should lead to higher economic growth. Finally, it should also reduce quantitative controls and allow interest rates to be market-determined (Adekunle \& Feyisayo, 2019).

Financial liberalization also provides numerous benefits leading to both domestic and foreign investments. At the external front, financial openness might create more substantial capital inflows with cheaper credit and more investment funds. The inflows of foreign savings augment the constraints on domestic investment, increased domestic competition, and technology transfers (Levine, 2005). At the same time, the inflows bring about volatility in the capital market and make the monetary policy a problematic task for policymakers. 
In Liberia, just like many other countries in Sub-Saharan Africa (SSA), it was encouraged in the 1980s to liberalize their financial systems in the hope of improving macroeconomic stability and achieving economic growth. Liberia implemented progressive financial liberalization policies in the mid-1980s, such as the elimination of interest rate subsidies to priority sectors, active management of reserve requirements, and more market-based allocation of refinancing. Furthermore, stock market legislation was updated, and the management transferred to the association of brokerage houses. A new banking law was enacted in Liberia to increase the autonomy of the central bank and prudential regulation in line with international standards as it was introduced. Finally, the banking sector was opened for foreign participation to increase competition in the sector.

However, financial liberalization seems to have been characterized by unpleasant developments, especially in its relationship with growth and savings. Specifically, the financial crises in the 1980s and 1990s and the associated decline in growth rate that rocked many African countries seem to have attributed to financial liberalization (Abiad, Detragiache \& Tressel, 2010).). For Liberia, the effect of financial liberalization has not given considerable attention even though the country was among the earliest countries in African countries to adopt financial liberalization reform. It is, therefore, necessary to fill the gap in the literature for Liberia, and thus this study investigates the impact of financial liberalization on economic growth in Liberia.

This study contributes to the existing literature in the following ways: first, it broadens financial liberation theory providing insights regarding financial liberalization and economic growth, specific factors that have important policy implications for the country. Second, it employed econometric techniques of Combined Cointegration tests, Dynamic Ordinary Least Squares (DOLS), and robustness checks of Fully Modified Ordinary Squares (FMOLS), and Canonical 
Cointegration Regression (CCR) to model Liberia economic data. Third, we control for several selected country-specific macroeconomic variables to examine the factors determining economic growth in Liberia. Finally, the findings may open a new chapter of debates among researchers and policymakers interested in developing the country.

The rest of this paper presents the following: Section 2 reviews the existing literature on financial liberalization and economic growth; section 3 presents the data sources and methodology; section 4 discussed the empirical findings; section 5 provides conclusion and policy remarks.

\section{Literature Review}

Financial sector development is pivotal to the efficacy of any economy since it enhances economic growth and investment. The contemporary arguments on the role of finance-growth nexus are rooted in theories. In this study, we focused on the proposition of McKinnon (1973) and Shaw (1973) classical assumption that savings determine full utilization of resources. In this study, we classified the theoretical literature into three generations: the First-Generation approach by Krugman (1979), the Second-Generation approach by Obstfeld (1996); and the Third-Generation approach again by Krugman (1998; 1999). However, a clear original McKinnon and Shaw contribution, which represents an increasingly sophisticated theoretical and empirical development of the original hypothesis, has been detected from the evolving literature (Fowowe, 2013).

The theory of McKinnon (1973) and Shaw (1973) propose that real deposit rates of interest on monetary assets are negative most of the time after accounting for inflation in a repressed financial market economy, and this does not encourage savings. The order of the day in such 
economies is that the lenders lose, while the borrowers gain. Hence, they argue that a higher real rate of interest on deposits should increase savings, which will increase the supply of loanable funds and ultimately lower the lending rate, increase investment and accelerate economic growth in the economy. They predict that if the deposit rate is allowed to be determined by the market, it will increase savings because the deposit rate will be higher, and this will attract more savings. Further, McKinnon (1973) and Shaw (1973) also argued a wide range of policy reforms, including abolishing the interest rates ceiling, reserve requirements, eliminate exchange controls, and liberalized the country's capital account. Based on the overreaching importance of deposit interest rates, savings, investment, and economic growth, many studies have focused on examining McKinnon (1973) and Shaw (1973) hypothesis.

Shrestha and Chowdhury's (2007) study noted that a well-functioning financial system is where the price mechanism money from the surplus unit to a deficit unit for investment. They expressed that interest rates have both the supply and demand side of credit. On the supply side, it is the opportunity cost, and at the demand side, it is the price to pay for using credit. The suppliers' opportunity cost must be high enough to surrender their funds for a specified period. The compensation to the supplier of loanable funds must include an adjustment for expected inflation. The real interest rate that adjusts for the anticipated inflation is vital for the supply and demand for loanable funds to appropriate the right benefit to each side.

The importance of correctly sequencing the process of financial liberalization in a stipulated order is essential. This strand of literature was brought to the fore following the pioneering experiences of early liberalizers in Latin America in the early 1980s, especially as both Chile and Argentina rapidly removed interest rate controls and allowed competition in the banking sector (Williamson \& Mahar, 1998). However, this liberalization reform process was hastily 
implemented without the necessary and appropriate macroeconomic environment (Williamson \& Mahar, 1998). This led economists and policymakers to immediately develop a sequencing framework necessary for the implementation of financial liberalization (ibid.):

- $\quad$ Ensure stability in the macroeconomic environment;

- $\quad$ Ensure the removal of international trade restrictions;

- $\quad$ Ensure the implementation of a robust regulatory and prudential framework;

- $\quad$ Ensure the removal of interest rate controls;

- $\quad$ Ensure the elimination of credit controls;

- $\quad$ Ensure the removal of competitive barriers; and

- $\quad$ Ensure the liberalization of capital accounts.

Williamson and Mahar (1998) noted that many of the essential preconditions were not in place in many developing countries before they embarked on financial liberalization reforms. For instance, exposing the domestic banking sector to foreign competition without an appropriate and effective regulatory and supervisory framework in place was a tendency to taken excessive risk. Therefore, implementing a robust regulatory and prudential framework is necessary as a disciplinary mechanism to keep banks' excessive risk behavior under control after liberalization.

Several authors (Roubini \& Sala-i-Martin, 1992; Seck \& El Nil, 1993; King \& Levine, 1993; Ogun, 1986; Charlier \& Oguie, 2002; Allen \& Ndikumana, 2000; Loayza et al., 2000; Chandrasekhar, 2007; Shrestha \& Chowdhury, 2007; Awan, Munir, Hussain \& Sher, 2010) found that the relationship between interest rates and saving is mixed. For instance, Charlier and Oguie (2002) and Shrestha and Chowdhry (2007) found that interest rate promoted savings, and also attained efficient allocation of financial resources. On the other hand, Roubini and Sala-iMartin (1992) found a negative relationship between saving and interest rates in a cross-sectional study of 98 countries. Ogun (1986) in a cross-sectional analysis of 20 countries in Africa from 
1969-1983 noted that high-interest rates on deposit interest enhanced savings, while Goldsmith (1969), Loayza et al. (2000) and Schmidt-Hebbel and Servén (2002) found that the relationship between the interest rate and savings was inconclusive.

Lewis (1992), Morisset (1993), Bascom (2016), and Eregha (2010) examined the relationship between interest rates and investment. Empirical evidence from these studies is also mixed. Lewis (1992) and Morisset (1993) found a positive effect of interest rates on investment, whereas Bascom (2016) and Eregha (2010) found that the effect of higher interest rates on investment is ambiguous.

The relationship between saving and economic growth has been difficult to test due to theoretical ambiguity, and the direction of the response of aggregate saving on economic growth remains highly controversial. Single country studies include Sothan (2014), Attanasio, Picci and Scorcu (2000), and Deaton and Paxson (2000). All of these studies, except Attanasio et al. (2000), found the weak effect of savings on economic growth. The cross-country studies of Thimann and Dayal-Gulati (1997), and Fatás (2000) remain controversial, with some authors claiming that growth induces saving. From all of these single country studies on this topic, there is none from Liberia: previous studies in the region have focused mainly on neighboring West African countries such as Nigeria, Ghana, Sierra Leone, and Ivory Coast (Fowowe, 2013).

Finally, empirical studies on the relationship between financial liberalization and economic growth remain inconclusive and debatable (Akinsola, \& Odhiambo, 2017; and Fowowe, 2013). On the whole most cross-country panel studies show a positive relationship between financial liberalization and economic growth (Tajudeen, Olusola \& Ademola, 2017; and Demirgüç-Kunt, \& Levine, 2018). On the other hand, most country-specific time-series studies show a negative 
and insignificant growth relationship (Oshikoya, 1994). Hence, no precise conclusion on the financial liberalization and economic growth relationship has been reached in the academic literature. These conflicting results raise doubts about the accuracy of the McKinnon (1973) and Shaw (1973) hypothesis. Thus, it is essential to empirically test the liberalization policies' effect on the Liberian economic growth by employing robust DOLS, FMOLS, and CCR econometrics analysis.

\section{Data}

The data employed in this research work are from secondary sources and are extracted from the World Bank database of World Development Indicators (WDI). The analysis used annual time series data that span between 1980 and 2016. The choice of selected sampling years is based solely on data availability and gives a total of 37 observations that constitutes a relatively large and sufficient sample size to carry out a statistically meaningful analysis. The choice of dependent variables such as gross domestic savings (Oshikoya, 1994), gross fixed investment (Seck \& El Nil, 1993; Akpokodje, 2000), and gross domestic product per capita (Ang \& McKibbin, 2005) were based on examples in extant studies. The choice of deposit interest rates as the variable of interest and proxy for financial liberalization is also based on examples from prior studies (Charlier \& Oguie, 2002; Ziorklui \& Barbee, 2003). All the control variables were carefully selected based on prior empirical studies (Ang \& McKibbin, 2005; Jun 2012). The summary of variables in this study and the summary of the descriptive statistics are present in table 1 and table 2 , respectively.

Insert table 1 here 


\section{Insert table 2 here}

\section{Methodology}

\subsection{Model Specification}

This study adopts the models used by Oshikoya (1994) and Seck and El Nil (1993). It tested the effect of interest rates on savings, investments, and, ultimately, economic growth. The empirical strategy is structured into three modified equations, known as the savings equation, the investments equation, and the economic growth equation, respectively. Therefore, the model specifications have threefold:

(i) Financial liberalization and saving

$$
\text { saving }=f(F L)+\text { others }+\varepsilon_{i}
$$

Where $F L$ implies deposit interest rates, and others represent the control variables employed in the savings equation model, which include liquid liabilities, lagged gross domestic savings, CPI, and gross national income per capita.

(ii) Financial liberalization and investment

$$
\text { Investment }=f(F L)+\text { others }+\varepsilon_{i}
$$

Where FL represents deposit interest rates, and others imply a range of control variables employed in the investment equation model, including real GDP, CPI, and gross fixed capital formation.

(iii) Financial liberalization and economic growth

$$
G D P P K=f(F L)+\text { others }+\varepsilon_{i}
$$


Where $F L$ stands for deposit interest rates and others represents a set of control variables included in the investment equation model, such as gross fixed capital formation, CPI, private domestic credit, and trade openness.

In time series analysis, it is always good to test for the non-stationarity of variables; it helps to determine the econometric methodology to adopt for the analysis. Empirical evidence provided by previous studies has highlighted the importance of testing breaks when investigating the order of integration (Türsoy, 2017). In particular, the traditional unit root could be biased when there is a structural break in a time series or might lead to a spurious regression, and this type of variable exhibits a random walk with drift. A variable is non-stationary if its mean and variance are a function of time. However, a variable might become stationary at levels, first difference. The commonly used stationarity tests are the Dickey-Fuller (DF) (1981) and Phillips-Perron (1988), Perron and Vogelsang (1992), and the Clemente et al. (1998) unit root tests.

However, the limitation of the Perron and Vogelsang (1992) unit root test, only one structural break is considered in the series to determine the correct order of integration. Data from Liberia is bound to be plagued with structural breaks considering the civil war period (an obvious example) which ravaged the country in the 1990s. We, therefore, introduce a crisis dummy variable to account for the period of the Liberian political crisis, which culminated in the civil war. The crisis dummy takes the value one in times of political crisis of 1986 to 2004 and the value zero in periods of political stability. Based on the explanations mentioned previously, this paper applies two kinds of unit root tests, namely the Dickey-Fuller (DF) (1981) and PhillipsPerron (1988).

Dickey and Fuller (1981) augment the conventional test by including extra lags of the 
differenced dependent variable to absorb serial correlation in the model. The model accomplished by augmenting the unit root equation to:

$$
\Delta x_{t}=\propto_{0}+\gamma t_{t}+(\phi-1) x_{t-1}+\sum_{i=1}^{p} \beta_{i} \Delta x_{t-p+1}+\varepsilon_{t}
$$

Whereas $\Delta$ is the first difference operator and the number of lagged differences of the dependent variable empirically and automatically established by either the Schwarz Information Criteria or the Akaike Information Criteria.

The Phillips-Perron (1988) stationarity test is a non-parametric test that relaxes several distributional assumptions about the residual. They consider a generalization of the DF approach by creating room for mild assumptions on the distribution of the random error term. While the usual property of constant variance and zero mean still apply; and argues that unit roots and structural breaks are closely related: if there is a structural break in the data, a traditional unit root test may be biased towards a false null hypothesis when the time series variable is trendstationary with a structural break. This study takes this potential problem into account; this study further employs the modified version of the ADF test (MDF) that accommodates the potential existence of structural breaks in the data. Perron (2017) includes both time trends and time at which structural changes occur in his Innovational Outlier $\left(\mathrm{IO}_{1}\right.$ and $\left.\mathrm{IO}_{2}\right)$ and additive Outlier (AO) models. The IO models represent gradual change, whereas the AO model represents rapid change or shift in the series. All the models considered report their asymptotic critical values (Zivot \& Andrews, 2002; and Perron, 2017).

If the unit root tests of variables of interest are not stationary at levels or if the variables have different levels of stationarity, it becomes important to find out if the variables are cointegrated before running an analysis with it. Statistically, cointegration is said to exist if a linear 
combination of non-stationary variables $\mathrm{I}(1)$ follows a stationary process $\mathrm{I}(0)$. Also, variables are cointegrated if they share the same stochastic trend over an extended period. The most common cointegration tests are the Engle-Granger Engel residual-based test and the Johansen approach. Bayer and Hanck (2013) provided a new framework to verify cointegration between the variables by combining the Engle and Granger (1987), Johansen (1988), Boswijk (1994), and Banerjee et al. (1998) cointegration methods. The Bayer and Hanck combined cointegration technique generates a joint t-statistic based on four cointegration methods. This combined method improves the power of cointegration and provides more conclusive results by combining the four individual cointegration tests. The equations below show the Fisher equation of Bayer and Hanck (2013):

EG-JOH $=-2[($ ProEG $)+($ ProJOH $)]$

EG-JOH-BOS-BAN $=-2[($ Promg $)+($ Probos $)+($ Proban $)+($ Projoh $)$

\subsection{Estimation Technique}

Following examples from Paradiso and Rao (2011), Adom and Kwakwa (2014), Malizard (2015) and Adom, Kwakwa and Amankwaa (2018), this study adopts three cointegrating regression models comprising DOLS, Fully Modified Ordinary Least Squares (FMOLS) and Canonical Cointegrating Regression (CCR) estimators with DOLS operating as the baseline model and the other two cointegrating models as the robustness check estimators. The use of dynamic cointegrating econometric models addressing issues of endogeneity, second-order bias, and serial correlation such as DOLS, FMOLS, and CCR is recommended in several studies (Stock and Watson, 1993; and Ibhagui, 2019).

\section{Empirical Findings}


This chapter presents and discusses the empirical analysis of the study. This chapter is structured into three main parts; first part discusses the summary statistics and the correlation coefficient using a pairwise correlation matrix. The second part discusses the pre-estimation tests, which consist of the unit root test and the co-integration analysis. The final part presents the empirical findings of the study. The breakpoint unit root test shows that all the variables became stationary at first FMOLS and CCR, which allows an analysis of variables in the same order of integration. However, a few variables including the ratios of gross savings, liquid liabilities, and trade to GDP as well as consumer price index were also stationary at levels, but the stationarity became even more robust at first difference (see Breakpoint Unit Root Test in Table 3)

\section{Insert table 3 here}

After verifying the unit root properties of the variables, the combined test of cointegration was implemented in order to analyze the long-run relationship between the variables. In general, cointegration equations follow a three-step procedure. First, estimated F-statistics values for the models (the optimal lag length, which was selected via the AIC criterion); and provides evidence for a long-run relationship between the two variables (Pesaran et al., 2001). Second, we analyzed long-run coefficients and error correction terms (ECT); the long-run coefficient for the Ratio of GDS, GFCF, and GDPPC was positive and significant at 5\%. The ECT is positive and statistically significant at 5\%. Finally, we employed the robustness combined cointegration test developed by Bayer-Hanck (2013), which consists of the joint tests of Engle and Granger (1987), Johansen (1988), Boswijk (1994), and Banerjee et al. (1998) was used, respectively. 
The cointegration result shows evidence of cointegration with the computed F-statistics value. The F-statistics values for Engle-Granger and Johansen (EG-JOH) and Engle-Granger, Johansen, Banerjee-Dolado-Mestre, and Boswijk (EG-JOH-BAN-BOS) are higher than the critical values of 5\%, and this indicates that the null hypothesis of no-cointegration cannot be rejected. The first two hypotheses of cointegrating equations are not presented in this study, to save space. The combined cointegration results and the critical values are in Table 4.

\section{Insert table 4 here}

\section{Empirical Results}

The regression analyses are conducted in order to determine the effect of interest rate liberalization on gross domestic savings, gross fixed capital formation, and economic growth. A critical review of the literature suggests that DOLS regression is a more robust and appropriate single-equation specification due to its ability to control for endogeneity, regressor simultaneity, and serial correlation, as well as improving regression estimates with relatively small samples (Stock \& Watson, 1993). In evaluating the robustness of the baseline DOLS regression estimates, the study applied the same equation models to alternative cointegrating econometric techniques of FMOLS and CCR. The details analysis of the regression results of the equation models is presented in Tables 5 to 7 .

\section{Deposit Interest Rates Liberalization and Gross Domestic Savings}

Table 5 presents the regression results of the effect of deposit interest rates liberalization on 
gross domestic savings using the baseline DOLS econometric method highlighted earlier. While the results of the DOLS regression show that the effect of deposit interest rate on gross domestic savings is positive and moderately significant at the 5 percent level of significance. We indicate that an increase in deposit interest rates due to financial liberalization policies would spur a corresponding increase in gross domestic savings in the economy. This result is in line with the McKinnon-Shaw hypothesis, which states that liberalizing deposit interest rates have a positive income effect on savings behavior in an economy. Also, it is consistent with empirical evidence by Seck and EL Nil (1993) and Athukorala and Sen (2004), whom all found a significant positive relationship between deposit interest rates and private as well as domestic savings following financial liberalization in selected developing economies.

However, the result contradicts the findings in many of the studies from sub-Saharan Africa which often find a negatively insignificant relationship between deposit interest rates and private domestic savings as was the case in studies in Kenya and Ghana (Oshikoya, 1994; Kariuki, 1995; Ziorklui \& Barbee, 2003). The persistent negative results emanating from many African studies may be due to the shorter time series data employed in the studies. Oshikoya (1994) used annual time series data for only 19 years from 1970 to 1989, Kiriuki (1995) used annual time series data for 22 years from 1968 to 1990, and Ziorklui and Barbee (2003) used annual series for 29 years from 1971 to 2000 . Therefore, the results obtained in the current study are more robust and reliable as it employed annual series from 1980 to 2016, comprising 36 observations with an intercept-trend specification for all three cointegrating equation models. Additionally, a dummy variable was also included in the model to account for the period of the political crisis, which takes the value zero for the period of political instability from 1986 to 2004 and 1 for the other years. The Durbin-Watson statistic of 2.021, as well as the adjusted R-squared of 100 percent, 
shows that there is no autocorrelation in the baseline equation, and all the variables included in the model have high explanatory power on the variation in gross domestic savings.

All the control variables included in the equation are statistically significant with the expected sign in the DOLS model except for the CPI variable: although it has the a priori expected negative sign, it is insignificant. The lagged gross domestic savings used as a control variable in this model is positive and statistically significant. The liquid liabilities variable is robustly significant at the 1 percent level of significance in the DOLS model. The inflation variable proxy by consumer price is appropriately signed with a negative coefficient but statistically insignificant. Furthermore, the gross national income per capita variable also indicates a positively significant relationship with gross domestic savings in the DOLS model.

\section{Robustness checks}

The results of both FMOLS and CCR regression used for robustness checks also indicate a positive and robustly significant effect of deposit interest rate on gross savings at the 1 percent level of significance. Although all but one of the control variables in the two robustness check models have the expected sign, they are either not significant or weakly significant. The lagged gross domestic savings used as a control variable in this model is positive and statistically significant across both econometric estimators. The liquid liabilities variable is positive and insignificant across the two models. The inflation variable is appropriately signed with a negative coefficient across all three models but only statistically significant in the CCR model. The FMOLS model result is a replica of the CCR model in terms of the degree of significance. Furthermore, the gross national income per capita variable also indicates a positive but insignificant relationship with gross domestic savings in the FMOLS, while the CCR model is 
negatively insignificant as presented in table 5 .

Insert table 5 here

\section{Financial Liberalization and Investment}

The result of the regression estimates the effect of deposit interest rates on investment proxied by the gross fixed capital formation in Table 6. The results of the regression demonstrate the existence of a strong and robust positive relationship between deposit interest rates and gross investment as the baseline DOLS regression coefficient for the deposit interest rate is statistically significant at the 5 percent level. The result suggests that an increase in deposit rates would lead to an increase in gross fixed investment. The results obtained from the three econometric regression models are in line both with the financial liberalization theory as outlined in the McKinnon-Shaw hypothesis and with intuitive expectation. The result is also consistent with evidence from several country-specific empirical studies from across developing economies including sub-Saharan Africa which found a positive and significant relationship between liberalized deposit interest rates and gross investment (Oshikoya, 1994; Asante, 2000; Tadeu \& Silva, 2013). The adjusted R-squared of 98 percent in the baseline model shows that all the variables included in the model have sufficient predictive power on the variation in gross fixed investment. Another test statistic that helps in detecting the presence of autocorrelation in a regression model is the Durbin-Watson statistic, which is at 2.051, indicating that there is no autocorrelation in the baseline equation. The model also includes a crisis dummy variable as well as a deterministic trend specification. 
All the control variables included in the equation are appropriately signed and statistically significant except for CPI in the baseline DOLS equation, which did have the expected negative sign but was statistically insignificant. The negative sign on the inflation variable on two models (FMOLS and CCR) is intuitive as inflation expected to have an inverse relationship with gross fixed investment in an economy.

\section{Robustness Checks}

The results of the three regressions demonstrate the existence of a strong and robust positive relationship between deposit interest rates and gross investment as the baseline DOLS regression coefficient for the deposit interest rate is statistically significant at the 5 percent level. The result suggests that an increase in deposit rates would lead to an increase in gross fixed investment. The results obtained from the three econometric regression models are in line both with the financial liberalization theory as outlined in the McKinnon-Shaw hypothesis and with intuitive expectation. While the beta coefficient of the FMOLS and CCR estimators indicate a positive effect with a 1 percent level of significance.

All the control variables included in the equation are statistically significant in all three econometric models except for CPI in the baseline DOLS equation, which did have the expected negative sign but was statistically insignificant. The negative sign on the inflation variable on the other two models (FMOLS and CCR) is intuitive as inflation is expected to have an inverse relationship with gross fixed investment in an economy (See table 6).

\section{Insert table 6 here}




\section{Financial Liberalization and Economic Growth}

The results of the regressions modeling the empirical effect of interest rates liberalization on economic growth are presented in Table 5. The result from across the three cointegrating regression models estimated in this section indicates a robust and positively significant relationship between deposit interest rates and economic growth at the 1 percent level of significance. The results are in line with the predictions of the McKinnon-Shaw hypothesis, which predicted a positive effect of interest rate liberalization on economic growth, and this is consistent with many empirical studies including Seck and El Nil (1993) and Charlier and Oguie (2002).

In terms of the control variables, the gross fixed investment variable is positive and robustly significant at the 1 percent level of significance across all three econometric estimators. The result implies that a one percent increase in gross fixed investment will result in a corresponding increase in GDP per capita by 0.67 percent. Another control variable that meets our a priori expectation is the inflation variable, which expected to hurt economic growth intuitively, and the results indicate a negatively significant effect at the 1 percent level of significance in all three econometric models.

The private domestic credit variable, which is the financial development indicator in the model, indicates a positively insignificant coefficient in the baseline DOLS model. However, in the other two alternative models of robustness analysis, the results unexpectedly show some negatively significant coefficients. Nevertheless, since Kao and Chiang (2000) argue that the baseline DOLS is a more asymptotically efficient and consistent estimator and thus outperforms the alternative FMOLS and CCR models, we shall stick with the results of the DOLS in cases where there are differences in the sign of the coefficients and level of significance. The trade 
variable also conforms to economic theory and intuition in that it carries a positive sign with robustly significant statistics at the 1 percent level of significance across all three econometric models. The result also suggests that trade has a significant positive relationship with economic growth.

In terms of the diagnostic statistic and information criteria for assessing the goodness of the model, the adjusted R-squared for the three cointegrating econometric models is $0.998,0.869$ and 0.848 , which implies that the variables included in the model correctly explain variations in the economic growth for Liberia.

The observed Durbin-Watson statistic in Table 7 shows 1.90; which is between the acceptable ranges of 1.50 - 2.50 (Zhu, 2012; Radojičić, Marković, \& Radonjić-Đogatović, 2014), also indicates that there is no first-order autocorrelation in the model. However, the observed rule for the Durbin-Watson statistic value is 2 or nearly 2 .

Following Stock and Watson (1993) and Hayakawa and Kurozumi (2008), we specify a case of the DOLS model with lags and no leads. The two studies argued that a dynamic OLS estimator without leads substantially outperforms one with leads and lags, especially in the case of Granger non-causality. Specifically, they argued that leads are unnecessary if the cointegrating error does not Granger-cause the first difference of I(1) variables that appear in the right-hand.

\section{Robustness Checks}

All the control variables included in the equation are statistically significant in all three econometric models except for CPI in the baseline DOLS equation, which did have the expected negative sign but was statistically insignificant. The negative sign on the inflation variable on the other two models (FMOLS and CCR) noted intuitive that inflation might have an inverse relationship with gross fixed investment in an economy (See Table 7). 


\section{Insert table 7 here}

\section{Conclusion and Policy Implications}

In conclusion, this study has established the relationship between financial liberalization and economic growth in Liberia using the combined cointegrating techniques for the previous 37 years of data. The DOLS, FMOLS, and CCR techniques were used to empirically expose the effect of deposit interest rate on investment proxied by gross fixed capital formation. Our findings reveal that (i) the methodological analysis shows that the effect of financial liberalization is not sensitive to the choice of an estimation technique between DOLS, FMOLS, and CCR. In terms of statistical relevance, the DOLS technique seems to show the most relevant effect of financial liberalization on economic growth compared to FMOLS and CCR technique (Kao \& Chiang, 2000). (ii) The baseline DOLS empirical regression coefficient demonstrates a strong and robust positive relationship between deposit interest rates and gross investment. Thus, supporting McKinnon (1973) and Shaw (1973) hypothesis. The result intuitively implies that financial repression does adversely affect savings mobilization, aggregate private investment, and economic growth in the Liberian economy. (iii) Deposit interest rates are central to savings mobilization with a resultant effect on the quantity and quality of investment and aggregate output in Liberia. The result of the positive effect of the findings on economic growth thus justified the introduction of more reforms in the financial sector of Liberia.

This study proposes some policy recommendations: first, robust prudential financial reform could help in making the financial sector more resilient, supple, deep, and overall economic 
growth of the country. Second, Policymakers must strive to maintain a stable macroeconomic environment where inflation and exchange rates are within desired levels. A poor macroeconomic environment would quickly erode the gains of the financial liberalization reforms. The development of a dynamic and robust financial system will efficiently utilize domestic and foreign resources and will ultimately help in achieving higher and sustainable economic growth. Finally, future research could extend this study by addressing these study limitations, such as by using quarterly data instead of an annual one to capture more detailed information regarding policy changes. Besides, corporate micro-level data help to explore other plausible channels through which financial liberalization could affect economic growth.

\section{References}

Abiad, A., Detragiache, E., \& Tressel, T. (2010). A new database of financial reforms. IMF Staff Papers, 57(2), 281-302.

Adom, P. K., Kwakwa, P. A., \& Amankwaa, A. (2018). The long-run effects of economic, demographic, and political indices on actual and potential CO2 emissions. Journal of environmental management, 218 , 516-526.

Adekunle, O., \& Adodo, F. L. (2019). Financial Liberalization and Export Promotion: Evidence From Nigeria (1987-2018). Available at SSRN 3473943.

Adom, P. K., \& Kwakwa, P. A. (2014). Effects of changing trade structure and technical characteristics of the manufacturing sector on energy intensity in Ghana. Renewable and Sustainable Energy Reviews, 35, 475-483.

Allen, D. S., \& Ndikumana, L. (2000). Financial intermediation and economic growth in Southern Africa. Journal of African economies, 9(2), 132-160.

Akinsola, F. A., \& Odhiambo, N. M. (2017). The impact of financial liberalization on economic growth in sub-Saharan Africa. Cogent Economics \& Finance, 5(1), 1338851.

Akpokodje, G. (2000). The effect of export earnings fluctuations on capital formation in Nigeria.

Ang, J. B., \& McKibbin, W. J. (2007). Financial liberalization, financial sector development and growth: evidence from Malaysia. Journal of development economics, 84(1), 215-233.

Athukorala, P. C., \& Sen, K. (2004). The determinants of private saving in India. World

Development, 32(3), 491-503.

Asante, Y. (2000). Determinants of private investment behaviour in Ghana.

Attanasio, O. P., Picci, L., \& Scorcu, A. E. (2000). Saving, growth, and investment: a macroeconomic 
analysis using a panel of countries. Review of Economics and Statistics, 82(2), 182-211.

Awan, R. U., Munir, R., Hussain, Z., \& Sher, F. (2010). Rate of interest, financial liberalization \& domestic savings behavior in Pakistan. International Journal of Economics and Finance, 2(4), 75.

Bascom, W. O. (2016). The economics of financial reform in developing countries. Springer.

Banerjee, A., Dolado, J., \& Mestre, R. (1998). Error-correction mechanism tests for cointegration in a single-equation framework. Journal of time series analysis, 19(3), 267-283.

Bayer, C., \& Hanck, C. (2013). Combining non-cointegration tests. Journal of Time series analysis, 34(1), 83-95.

Levine, R., Loayza, N., \& Beck, T. (2000). Financial intermediation and growth: Causality and causes. Journal of monetary Economics, 46(1), 31-77.

Boswijk, H. P. (1994). Testing for an unstable root in conditional and structural error correction models. Journal of econometrics, 63(1), 37-60.

Bumann, S., Hermes, N., \& Lensink, R. (2013). Financial liberalization and economic growth: A meta-analysis. Journal of International Money and Finance, 33, 255-281.

Chandrasekhar, C. P. (2008). Financial liberalization and the new dynamics of growth in India. Third World Network.

Charlier, F., \& Oguie, C. N. C. (2002). The Impact of Interest Rate Liberalization: Empirical Evidence from Sub-Saharan Africa/L'impact De la Libéralisation des Taux D'intérêt: Analyse Empirique en Afrique SubSaharienne. Savings and Development, 355-380.

Clemente, J., Montañés, A., \& Reyes, M. (1998). Testing for a unit root in variables with a double change in the mean. Economics Letters, 59(2), 175-182.

Deaton, A., \& Paxson, C. (2000). Growth and saving among individuals and households. Review of Economics and Statistics, 82(2), 212-225.

Demirgüç-Kunt, A., \& Levine, R. (2018). Finance and growth. Edward Elgar Publishing Limited.

Dickey, D. A., \& Fuller, W. A. (1981). Likelihood ratio statistics for autoregressive time series with a unit root. Econometrica: journal of the Econometric Society, 1057-1072.

Engle, R. F., \& Granger, C. W. (1987). Co-integration and error correction: representation, estimation, and testing. Econometrica: journal of the Econometric Society, 251-276.

Eregha, P. B. (2010). Interest rate variation and investment determination in Nigeria. International Business Management, 4(2), 41-46.

Fatás, A. (2000). Endogenous growth and stochastic trends. Journal of Monetary Economics, 45(1), 107128.

Fink, A. (1995). How to analyze survey data (Vol. 8). Sage.

Fowowe, B. (2013). Financial liberalization in Sub-Saharan Africa: What do we know?. Journal of Economic Surveys, 27(1), 1-37.

Raymond, G. (1969). Financial structure and development. New Haven: Yale University Press. 
Hayakawa, K., \& Kurozumi, E. (2008). The role of "leads" in the dynamic OLS estimation of cointegrating regression models. Mathematics and Computers in Simulation, 79(3), 555-560.

Ibhagui, O. W. (2019). Does the long-run monetary model hold for Sub-Saharan Africa? A time series and panel-cointegration study. Research in International Business and Finance, 47, 279-303.

Johansen, S. (1988). Statistical analysis of cointegration vectors. Journal of economic dynamics and control, 12(2-3), 231-254.

Jun, S. (2012). Financial development and output growth: A panel study for Asian countries. Journal of East Asian Economic Integration, 16(1), 97-115.

Kariuki, P. W. (1995). The impact of interest rate liberalisation on financial savings: The case of Kenya. African Review of Money Finance and Banking, 5-23.

King, R. G., \& Levine, R. (1993). Finance and growth: Schumpeter might be right. The quarterly journal of economics, 108(3), 717-737.

Baltagi, B. H., \& Kao, C. (2000). Nonstationary panels, cointegration in panels and dynamic panels: A survey. Syracuse University Center for Policy Research Working Paper, (16).

Krugman, P. (1979). Increasing returns, monopolistic competition, and international trade.

Krugman, P. (1999). Balance sheets, the transfer problem, and financial crises. In International finance and financial crises (pp. 31-55). Springer, Dordrecht.

Lewis, J. D. (1992). Financial repression and liberalization in a general equilibrium model with financial markets. Journal of Policy Modeling, 14(2), 135-166.

Levine, R. (2005). Finance and growth: theory and evidence. Handbook of economic growth, 1, 865-934.

Malizard, J. (2015). Does military expenditure crowd out private investment? A disaggregated perspective for the case of France. Economic Modelling, 46, 44-52.

Wells, D. A. (1974). McKinnon, Ronald I., Money and Capital in Economic Development, Washington, DC, The Brookings Institution, 1973, xii+ 184 pp.(\$7.50).

Morisset, J. (1993). Does financial liberalization really improve private investment in developing countries?. Journal of development economics, 40(1), 133-150.

Obstfeld, M. (1996). Models of currency crises with self-fulfilling features. European economic review, 40(3-5), 1037-1047.

Ogun, O. D. (1986). A note on financial deepening and economic growth: Evidence from Africa. The Nigerian Journal of Economic and Social Studies, 28(2), 275-283.

Oshikoya, T. W. (1994). Macroeconomic determinants of domestic private investment in Africa: An empirical analysis. Economic development and cultural change, 42(3), 573-596.

Paradiso, A., \& Rao, B. B. (2011). How to offset the negative trend growth rate in the Italian economy?. Applied Economics Letters, 18(15), 1479-1483.

Phillips, P. C., \& Perron, P. (1988). Testing for a unit root in time series regression. Biometrika, 75(2), 335-346. 
Perron, P., \& Vogelsang, T. J. (1992). Testing for a unit root in a time series with a changing mean: corrections and extensions. Journal of Business \& Economic Statistics, 10(4), 467-470.

Perron, P. (2017). Unit roots and structural breaks.

Pesaran, M. H., Shin, Y., \& Smith, R. J. (2001). Bounds testing approaches to the analysis of level relationships. Journal of applied econometrics, 16(3), 289-326.

Radojičić, V., Marković, G., \& Đogatović, V. R. (2014). Market Share Forecasting of Mobile Telephony in Serbia. In Second International Conference on Traffic and Transport Engineering (ICTTE).

Roubini, N., \& Sala-i-Martin, X. (1992). Financial repression and economic growth. Journal of development economics, 39(1), 5-30.

Seck, D., \& El Nil, Y. H. (1993). Financial liberalization in Africa. World Development, 21(11), 1867-1881. Shaw, E. S. (1973). Financial deepening in economic development.

Shrestha, M. B., \& Chowdhury, K. (2007). Testing financial liberalization hypothesis with ARDL modelling approach. Applied Financial Economics, 17(18), 1529-1540.

Sothan, S. (2014). Causal relationship between domestic saving and economic growth: Evidence from Cambodia. International Journal of Economics and Finance, 6(9), 213.

Stiglitz, J. E. (2000). Capital market liberalization, economic growth, and instability. World development, 28(6), 1075-1086.

Stock, J. H., \& Watson, M. W. (1993). A simple estimator of cointegrating vectors in higher order integrated systems. Econometrica: Journal of the Econometric Society, 783-820.

Tajudeen, E., Olusola, A. T., \& Ademola, B. A. G. (2017). Interest rate liberalization, financial development and economic growth in Sub-Saharan African economies. African Journal of Economic Review, 5(2), 109-129.

Tadeu, H. F. B., \& Silva, J. T. M. (2013). The determinants of the long term private investment in Brazil: an empyrical analysis using cross-section and a Monte Carlo simulation. Journal of Economics Finance and Administrative Science, 18, 11-17.

Thimann, M. C., \& Dayal-Gulati, M. A. (1997). Saving in Southeast Asia and Latin America compared: searching for policy lessons (No. 97-110). International Monetary Fund.

Türsoy, T. (2017). Causality between stock prices and exchange rates in Turkey: Empirical evidence from the ARDL bounds test and a combined cointegration approach. International Journal of Financial Studies, 5(1), 8.

Williamson, J., \& Mahar, M. (1998). A survey of financial liberalization (No. 211). Princeton Univ International Economics.

Zhu, Y. (2012). Multisensor decision and estimation fusion (Vol. 14). Springer Science \& Business Media. Ziorklui, S. Q., \& Barbee Jr, W. (2003). Financial sector reform and financial savings in sub-Saharan Africa: the case of Ghana. Savings and Development, 63-78.

Zivot, E., \& Andrews, D. W. K. (2002). Further evidence on the great crash, the oil-price shock, and the unit-root hypothesis. Journal of business \& economic statistics, 20(1), 25-44. 